\section{International forum backs ban}

\section{Canberra}

A PROPOSED international ban on the production and stockpiling of chemical weapons could push up the worldwide price of chemicals by one-quarter per cent. According to Tom Reynolds, head of Australia's industry delegation to the international Government-Industry Against Chemical Weapons Conference held in Canberra last week, consumers would have to bear the $\$ 1,000$ million cost to industry of the new treaty.

The ban received the unanimous support of representatives of 95 per cent of the world's chemical industry, including those from Iraq and Iran, which were accused of using chemical weapons during the Gulf War. The aim of the conference was to bring government and industry together to discuss the practicalities of an international ban on chemical weapons.

Much of the proliferation in chemical weapons seen in the past decade has been linked to the production of chemicals by private industry, without governmental control. The chemicals that provide precursors to those used in weapons have a wide range of civilian applications.

Chemical weapons have been on the

for import of the latest foreign technology and, according to Nikkei Biotechnology, the Red Cross has already approached Baxter.

But in the United States, blood coagulants produced by the monoclonal-antibody technique are much more expensive than conventional coagulants and are beyond the reach of many haemophiliacs. Given the high price of blood plasma in Japan, it seems certain that the price of domestically produced coagulants will be high. Seizo Murakami, chairman of the blood business promotion council, says the council has "no idea" what the price of Red Cross coagulants will be.

Blood-product manufacturers refuse to comment on the report. But a representative of the Chemo-Sero-Therapeutic Research Institute (Kaketsuken), a manufacturer in Kyushu, at a press conference last year, complained bitterly that the Red Cross had made requests for transfer of its blood-product manufacturing technology. And, according to a reliable source, Kaketsuken is "furious" about the council's recommendations.

Mitsuru Miyata, editor of Nikkei Biotechnology, says that Japan's four bloodproduct manufacturers (Kaketsuken, Midori Juji, Fuji Rebio and Nihon Seiyaku) realize that blood products are unlikely to be profitable and are diversifying into new areas. But it seems unlikely that the Red Cross will be able to replace their expertise in research and development.

David Swinbanks agenda in the Geneva arms-control negotiations since 1968. In Paris earlier this year, 149 nations met for a conference on the prohibition of chemical weapon use.

Four hundred delegates from 60 countries, excluding Libya and Syria which chose not to attend, were present in Canberra. The Soviet Union and the United States are the only two countries to admit to having chemical weapons, although another 20 countries are believed to have the capability to produce them. The United States is the only country that admits to producing chemical weapons.

The conference agreed to the formation of an industry forum to lobby in Geneva for an early signing of a treaty. Signing is unlikely to take place before 1992, but there was general agreement that political and technical issues could be worked out by the end of 1990 .

Important elements of the proposed treaty will be a combination of regular and impromptu inspections of each participaover commercial confidentiality was partially allayed by a call for amendments to the treaty protecting the confidential transfer of data between industry and the national governments of the inspectors. "This will give industry some confidence that their trade secrets won't suddenly come out in the public domain", said Reynolds.

Challenge inspections would be conducted by an agency similar to the International Atomic Energy Agency, a multilateral organization that inspects nuclear power plants worldwide. Such a secretariat would cost $\$ 100$ million a year.

There was little agreement, however, on how to deal with countries that break the treaty. "In the end there is no international police force; if a country is determined to break its obligations, it can. If a signatory does not comply with the verification procedures outlined in the treaty, then it is no longer a party to it, and industry would suffer if it dealt with that country," said Michael Costello, delegation leader for Australia.

Both the Soviets and the Americans were eager to be the first to announce initiatives. The Soviets claimed to be the first to agree to the challenge inspections "anytime, anywhere". The US delegates countered with then-Vice President George Bush's 1984 speech urging impromptu inspections.

Nikita Smidovich, head of the Soviet arms control and disarmament section called the Americans "double-faced" because of their continued production of chemical weapons while advocating nonproliferation and an eventual ban. The United States ceased production of chemical weapons in 1969 and resumed in ting nation's chemical plants. Concern
1988, because its stockpile was no longer considered a credible deterrent to the Soviet Union, which did not cease production until 1987.

With the world's chemical industries opposing all "diversion of industry's products for the manufacture of chemical weapons", the US government may have to make its own chemicals to avoid forcing its industry to break the agreement. According to Kyle Olson, one of the US industry representatives, the Americans are getting at least some of their chemicalweapon products on the open market. The US ambassador to the Geneva weapons talks, Max Friedersdorf, said that as chemical weapons were being produced with congressional approval, the use of commercial products in chemical weapons did not constitute a "diversion of industry products."

Tania Ewing

\section{... . and so does Bush \\ Washington}

IN his first speech before the United Nations General Assembly last Monday, US President George Bush proposed steps towards a worldwide ban on the production and stockpiling of all chemical weapons. The proposal followed a successful weekend meeting in Jackson Hole, Wyoming, between Secretary of State James Baker and Soviet Foreign Minister Eduard Sheverdnadze, at which the United States and the Soviet Union agreed to provide information on their chemicalweapons arsenals and allow mutual inspection of storage sites.

Bush said that the United States is ready to destroy "98 per cent" of its chemical weapons stockpile in the first eight years of a new treaty, provided the Soviet Union joins the ban, and to destroy "every one" of its chemical weapons within ten years once all nations capable of producing chemical weapons sign the treaty.

A major new element of the proposal is the willingness of the United States to begin chemical weapons cuts before an international treaty is concluded. "The United States is ready to begin now", said Bush, and is prepared to eliminate "more than 80 per cent" of its chemical weapons before a treaty is signed, provided only that the Soviet Union reduces its stockpile to an equal level and there is agreement on the conditions, including inspection, under which stockpiles are to be destroyed.

The Bush proposal is partly seen as an attempt by the United States to regain the momentum lost to the Soviet Union in global arms-control negotiations. But the willingness of the United States to begin making cuts immediately is clearly intended to have a wider effect, pushing forward the 40-nation negotiations at Geneva on a chemical-weapons ban.

Alun Anderson 